\title{
A Foundation for the Scientific Research on Eroticism and Sexuality
}

\author{
Ad van der Ven* \\ Department of Pedagogy, Institute for Learning and Development, Radboud University Nijmegen, The Netherlands
}

Submission: October 19, 2020; Published: November 09, 2020

*Corresponding author: Ad van der Ven, Department of Pedagogy, Institute for Learning and Development, Radboud University Nijmegen, Thomas van Aquinostraat 4, 6525 GD, Nijmegen, The Netherlands

Keywords: Psychology; Eroticism; Sexuality; Retardation Theory.

\section{Opinion}

For the development of a psychology of eroticism and sexuality it is necessary to consider the first and second retardation theory. The first theory of retardation says that man is fundamentally different in his development from the primates (ape-like). Considering the time, it takes for the primates to reach maturity, it is in the order of one to two years. In humans there is a delay (retardation). It takes about ten years. Hence, sexual maturity in humans does not take place until the eleventh to twelfth year. It is no coincidence that this is happening. Man also differs from all other animals in the fact that man has the third degree capacity (the ability to think). According to the author León [1] the book The World Solution for World Problems (personal communication), all life forms, as they occur on Earth, occur in three fundamentally different degrees:

a. zero degree: non-life, is moved (allo-motion), does not move by itself (auto-motion),

b. first degree: vegetable, moves by itself (auto-motion), does not move by itself from place to place (auto-locomotion),

c. second degree: animal, moves by itself from place to place (auto-locomotion), does not move by itself virtually from place to place (allo-imagination),

d. third degree: human, moves by itself virtually from place to place and from moment to moment (auto-imagination $=$ mind).
In order to make auto-locomotion possible in the second degree, a movement device is needed, such as the legs in landdwelling animals, fins in fish and wings in birds. For the third degree, an intermediary is also needed to make the mind function and that is language. Language is primarily a tool for thinking along. Only in the second place is it a means of communication. In the course of history, the use of the third degree leads to applicable knowledge. In order to pass on language and knowledge from generation to generation, a period in life is needed, in which everything that has to do with reproduction does not yet play a role. That period is the period of childhood (the first period of retardation). The existence of the first period of retardation and the fact that man is a mind-driven animal (Latin: animal rationale), i.e. a third degree life form, are therefore closely linked. The idea that childhood is essentially a form of developmental retardation is also noted by Remplein [2]:

Diese Theorie von der Entwicklungshemmung der species Mensch trägt nicht nur der Verwandtschaft von Affe und Mensch Rechnung, sondern erklärt auch viele Einzeltatsachen: z.B. die einmalig lange Kindheit, d.h. den unverhältnismäßig späten Eintritt der Pubertät des Menschen, seine lange Lebensdauer, die auffallende morphologische Ähnlichkeit von Anthropoiden- und Menschenbabys bei großer eindrucksmäßiger Verschiedenheit der erwachsenen Anthropoiden und Menschen. (Remplein, 1969, page 49; boldface by the author).

${ }^{1}$ The book is also available as an eBook at the Library of the Radboud University Nijmegen 
This theory of the developmental inhibition of the human species takes into account not only the relationship between apes and humans, but also explains many individual facts: for example, the uniquely long childhood, i.e. the disproportionately late onset of puberty, its long lifespan, the striking morphological similarity of anthropoids - and human babies, with great impressive diversity of adult anthropoids and humans. (translated by the author; boldface by the author).

However, when humans reach sexual maturity, a second retardation takes place. What exactly is happening? The 'female' retains the characteristics of the 'junghaft' (youthful, high voice, blond hair in the white race, deep black hair in the dark races, no extra hair like a beard, etc., etc.). There is of course the development of secondary sexual characteristics such as breast development, pubic hair, widening of the pelvis, etc.). The idea of a second retardation that only occurs in women is also mentioned by Remplein:

Dank der früheren Beendigung der Reifung bewahrt die Frau durchschnittlich mehr von der kindlichen Lebensform: schon in den runden Körperformen (u.a. in der steileren, schöner gewölbten Stirn) und noch mehr in der seelischen Struktur (Integration, Gefühlsbetontheit, Umweltverbundenheit, ganzheitliche Auffassung gegenständliches Denken usw.). (Remplein, 1969, page 538; boldface by the author).

Thanks to the earlier termination of the maturation, on average, the woman keeps more of the child's physical and mental appearance: already in the round body shapes (including the steeper, more beautifully arched forehead) and even more in the mental structure (integration, emphasis on feeling, closeness to the environment, holistic view, objective thinking, etc.). (translation by the author; boldface by the author).

Due to the second retardation, the encounter between the sexes is essentially different from all other animal species, especially the mammals and more specifically the great apes. The 'male' initially sees the 'young' in the 'female' and, at first, will tend to 'brut pflege'-like protecting, feeding and holding the 'young'. The latter is the case because, evolutionarily speaking, humans may have lived in trees. We see the tendency towards 'protection' in the ideal of knighthood. In the period just before the emergence of the third degree (the mind) in humans, the nutrition after breastfeeding changed into the transfer of the chewed food from mouth to mouth (putting the food in the mouth of the 'young' ), in which the tongue also played an important role. Nowadays we see this in the tendency of the 'male' to kiss the 'female' and that also with the so-called 'French kiss'. Wickler [3] devotes an entire chapter to this subject ([3] page 210-217). He writes, among other things:

Van mond tot mond voeren maakte nog heel kort geleden deel uit van de normale kinderverzorging bij diverse natuurvolkeren, bijvoorbeeld op de Carolinen, op Samoa, bij Nagastammen in Assam en bij Papoea stammen in West-Irian. (Wickler, 1969, page 210).
Mouth-to-mouth feeding was very recently still part of the normal child care routine of various wildlife peoples such as the Carolines, Samoa, Naga tribes in Assam and Papuan tribes in West Irian. (translation by the author).

Now the drive system that leads to 'brutpflege' (eroticism) leads to a completely different behavior than the drive system that leads to copulation (sexuality). Hence one always sees two phases between the sexes in their approach to each other. The first phase, the erotic phase, is actually not directly aimed at copulation. This phase turns into the second phase, the actual sexual phase, and only then does behavior aimed at copulation take place. Further research should now focus on finding an answer to the question of exactly how this transition from eroticism to sexuality takes place. Now it is known from ethology that every drift system needs a trigger to work. For men, these are certain specific characteristics of the woman's appearance that can be summed up as 'handsome' or 'pretty' and the trigger effect is experienced as 'infatuation'. It is still unclear what these characteristics are exactly. Whether there is a trigger in the woman, which she experiences when she meets man, remains to be answered and if such a trigger exists, it is also the question what that trigger would be exactly.

The behavioral implications of the theoretical assumptions presented here may be clouded by other factors that may also play a role in the development of feelings and behaviors related to eroticism and sexuality. One of these factors can be a non-optimal mother-child relationship in the period immediately after the birth of the child. Wickler says the following about this:

Ook de mensenbaby is nestblijver noch nestvlieder, maar net als de chimpanseebaby een 'moederblijver' die in zijn eerste levensperiode permanent op het lichaam van de moeder zou moeten worden meegedragen, zoals nog altijd bij de natuurvolken gebeurt. Daar is het hele gedrag van de pasgeborene op ingesteld. De mens is namelijk niet, zoals vaak wordt beweerd, een wezen dat fysiologisch te vroeg geboren wordt. Hij beschikt integendeel van zijn geboorte af over alle bewegingsmogelijkheden waardoor hij op het lichaam van de moeder kan leven. Hij klemt zich ook graag vast, vooral - zoals iedereen weet - graag aan haren. De scheiding van de moeder maakt de zuigeling pas in de ware zin van het woord zo 'hulpeloos'. Dat we de zuigelingen in een wieg neerleggen is onbiologisch. Aanwijzingen daarvoor zijn het abnormaal veel voorkomende huilen omdat ze zich verlaten voelen, iets wat bij kinderen van natuurvolken haast nooit te horen is, en de 'namaakcontacten' die de baby geruststellen do ordat ze hem een lichamelijk contact met de moeder suggerreren: de speen en het schommelen van wieg of kinderwagen. ([3] page 233 - 234).

The human baby is neither a nest-keeper nor a nest-bird, but just like the chimpanzee baby a 'mother-stayer' who should be carried permanently on the body of the mother during its first period of life, as is still the case with the wild people. The entire behavior of the newborn is geared to this. For man is not, as, is often said, a being born physiologically prematurely. On the contrary, from birth on he has all the possibilities of movement that allow him 
to live on the body of the mother. He also likes to cling, especially, as everyone knows, to hair. The separation from the mother only makes the infant "helpless" in the truest sense of the word. The fact that we put the infants in a cradle is unbiologic. There are abnormally many indications for this such as often crying,- because they feel abandoned, something that is almost never heard with children of wild people and the "fake contacts" that reassure the baby by suggesting physical contact with the mother: the teat and the rocking of the crib or pram. (translation by the author).

This initially experienced absence of the mother can lead to an unconscious search for confirmation that is yet to be experienced when meeting the opposite sex in a later period of life. However, further research must determine whether this unconscious search for confirmation is indeed the case and how that leads to something like 'falling in love'. In this article, childhood has been designated as the first retardation period and the preservation of the childlike appearance by the woman as the second retardation. However, there is a theory in which it is assumed that there was already a developmental delay (retardation) during the fetal period. This theory is known as Bolk's fetalization theory about the human body (see Wikipedia). Remplein [2] says the following about this theory:

Will man die Deszendenztheorie trotzdem aufrechterhalten, dann sieht man sich zu der Annahme genötigt, daß sich der Mensch aus seinem relativ unspezialisierten Anthropoiden entwickelt habe. Die beste Begründung hierfür stammt von dem Amsterdamer Anatomen L. Bolk. Er untersucht die morphologischen Merkmale, welche dieSonderstellung des Menschen begründen: Orthognathie (Unterstellung des Gebißteil unter den Hirnteil), Unbehaartheit, Pigmentverlust in Haut, Haaren und Augen, Form der Ohrmuschel, Mongolenfalte, zentrale Lagedes Hinterhauptslochs, hohes Hirngewicht, Weiterbestehen der Schädelnähte, Bau von Hand und Fuß, Form des Beckens, große Schamlippen und bauchwärts gerichtete Lage der Geschlechtsspalte beim Weibe. Vergleichende Betrachtung zeigt, daß alle diese Merkmale beim Fötus der Primaten vorübergehend auftreten und nur vom Menschen auch im postfötalen Zustand festgehalten werden. Demnach darf man diese Formeigentümlichkeiten des Menschen als permanent gewordene fötale Zustande ansehen. Fragt man, wie es zu diesem Beharren gekommen sei, so bietet sich als Denkmöglichkeit eine endokrin bedingte Verzögerung oder Retardierung der menschlichen Entwicklung an. (Remplein, 1969, page 48 - 49).

If one still wants to maintain the theory of descent, one sees the necessity to assume that humans have developed from a relatively unspecialized anthropoid. The best reason for this comes from the anatomist $L$ Bolk from Amsterdam. He examines the morphological features of the special position of humans: orthognathy (placement of the dentition under the brain part), hairlessness, pigment loss in skin, hair and eyes, shape of the auricle, Mongolian fold, central position of the occipital high brain weight, continued existence of the skull sutures, construction of hand and foot, shape of the pelvis, large labia and belly-facing position of the sex gaps in women. Comparative analysis shows that all these characteristics occur temporarily in the primates fetus and are only recorded by humans in the post-fetal state. Accordingly, these peculiarities of the human can be regarded as fetal states that have become permanent. If one asks how this persistence came about, an endocrine-related delay or retardation of human development offers itself as a way of thinking. (translated by the author; boldface by the author).

If, in accordance with Bolk's theory, one was to label the fetal period as the first retardation period, then childhood should be designated as the second retardation period and the period from the onset of female sexual maturity as the third retardation period. Earlier in this article, it was said that the behavioral implications of the theoretical assumptions presented may be clouded by other factors that may also play a role in the development of feelings and behaviors related to eroticism and sexuality. The question then arises of how the research could be done to investigate these factors. One possible way could be to use guided imagery. During psychotherapy sessions it happens repeatedly that people experience imagery. Imagery during therapy is mentioned by several authors: Freud himself, but also other psychologists and psychiatrists wrote about it. The term 'imagery' has different meanings in English. A distinction can be made between images perceived during dreams, hallucinations and fantasies. What is understood by imagery in this article comes closest to what McKellar describes as 'dreamlike imagery':

Some people in the drowsy state before sleep report an anticipatory invasion of consciousness by visual or other dreamlike imagery. (McKellar, page 40 in Sheehan, 1972).

In the meantime there exists already a journal devoted entirely to this subject: Journal of Mental Imagery. An example of guided imagery can be found on an Internet site entitled: Oefeningen in beeldwaarneming ${ }^{2}$ (English: Exercises in imagery), where the author reports on a series of imagery sessions on different subjects such as, for example, aura perception.

\section{References}

1. León L (1988) The world-solution for world-problems: the problem, its cause, its solution. Personal Edition, Nijmegen, The Netherlands.

2. Remplein H (1969) Die seelische Entwicklung des Menschen im Kindes- und Jugendalter. Grundlagen, Erkenntnisse und padagogische Folgerungen der Kindes- und Jugendpsychologie. Reinhardt, München Basel.

3. Wickler W (1969) De aard van het beestje. (English: The nature of the beast.) Uitgeverij Ploegsma, Amsterdam, the Netherlands. Dutch translation of Sind wir Sünder? Droemer Knaur, Münich / Zürich, Germany.

4. Sheehan PW (1972) (Ed) The function and nature of imagery. Academic Press, New York, United States.

${ }^{2}$ See: http://www.socsci.ru.nl/advdv/imagine/imagine.html 


\section{Your next submission with Juniper Publishers will reach you the below assets}

- Quality Editorial service

- Swift Peer Review

- Reprints availability

- E-prints Service

- Manuscript Podcast for convenient understanding

- Global attainment for your research

- Manuscript accessibility in different formats

( Pdf, E-pub, Full Text, Audio)

- Unceasing customer service

Track the below URL for one-step submission https://juniperpublishers.com/online-submission.php 